\title{
THE PROTEOLYTIC ENZYME TEST FOR DETECTING INCOMPLETE ANTIBODIES
}

\author{
BY \\ J. A. MORTON AND M. M. PICKLES \\ From the Division of Laboratories, United Oxford Hospitals
}

(RECEIVED FOR PUblication JANUARY 4, 1951)

The specific agglutination by incomplete anti $\mathrm{D}$ antibodies of a saline suspension of red cells, after preliminary incubation with a solution of crystalline trypsin, has been previously reported (Morton and Pickles, 1947). During the past two years this method has been standardized and used as a test for the detection of incomplete antibodies. The trypsin-treated cells have been found to give reliable results and to be more sensitive than the concentrated albumin (Diamond and Denton, 1945) and anti-globulin (Coombs, Mourant, and Race, 1945) methods in the detection of weak incomplete anti $\mathrm{D}$ antibodies. The utilization of trypsin-treated red cells for the routine detection of anti $\mathrm{Rh}$ antibodies has been reported by Wheeler, Luhby, and Scholl (1950) and also in the studies of haemagglutinins in congenital and acquired haemolytic anaemias by Wright, Dodd, and Bouroncle (1949).

In view of the high cost of the crystalline trypsin previously used from the Plaut Research Laboratory, New Jersey, and of the unreliability of some of the commercial varieties of trypsin which have been tested, a search has been made for other proteolytic enzymes which would react in the same manner. This paper reports an investigation of proteolytic enzymes which could be used as a substitute for crystalline trypsin, the standardization of the test, and its reliability and specificity as a result of two years' experience in routine antibody determinations.

\section{Proteolytic Enzymes as a Substitute for Trypsin}

Crude filtrates of various organisms known to have proteolytic activity have been tested for their ability to imitate the action of trypsin on red cells.

The following organisms were grown in broth culture and on $0.5 \%$ heart agar and the filtrates examined at intervals from two to 14 days.

B. subtilis; B. cereus; B. circulans; B. licheniformis; Proteus; Ps. pyocyanea; Actinomyces A 13; Actinomyces Polychrom NCTC 4599; Actinomyces Ruber; Streptomyces sp. (Dunn School of Pathology, Oxford); Streptomyces albus (Maxted, 1948). albus.

The only organisms found to show specific effects were the two strains of Streptomyces

In addition, commercial preparations of papain, pepsin, and trypsin were tested, and crystalline trypsin (Armour) and B.D.H. trypsin commercial and "refined" were found to give reliable results. The glycerol in solutions of trypsin such as liquor trypsini co. (Allen and Hanburys) often caused haemolysis of the red cells in the effective range of enzyme concentration. Papain solutions $1 \%$ and $10 \%$ were found to be suitable, but in view of the difficulty of standardizing the $\mathrm{E}^{\mathrm{H}}$ were not intensively investigated. The pepsin solution was found to be inactive. 


\section{Preparation of Stock Enzyme Solutions}

Commercial or refined trypsin powder (B.D.H.) was mixed with $0.05 \mathrm{~N} \mathrm{HCl}$ in the proportions of $200 \mathrm{mg}$. to $1 \mathrm{ml}$., shaken at intervals, and left overnight at $4^{\circ} \mathrm{C}$. The following day the supernatant fluid was removed after spinning down the undissolved particles and the solution kept at $4^{\circ} \mathrm{C}$. Crystalline trypsin (Plaut Research Co., New Jersey, and Armour Laboratories) containing $50 \% \mathrm{MgSO}_{4}$ was made up as a solution of $10 \mathrm{mg} . / \mathrm{ml}$. in $0.05 \mathrm{~N} \mathrm{HCl}$. These acid solutions have shown no diminution in activity over a period of four months. Immediately before use the stock enzyme preparations were diluted $1: 10(\mathrm{v} / \mathrm{v})$ with $0.1 \mathrm{M}$ phosphate buffer $p \mathrm{H}$ 7.7.

Streptomyces albus spores were sown on a $1.25 \%$ agar medium in Roux bottles as described by Maxted (1948). After four to six days at $30-37^{\circ} \mathrm{C}$., when good sporulation is usually observed, the bottles were placed at $-20^{\circ} \mathrm{C}$. for 12 hours and then allowed to thaw out, and the fluid which separated from the agar was passed through a Seitz filter. Stock filtrates were kept frozen at $-20^{\circ} \mathrm{C}$., but for daily use they were kept sterile by the addition of an equal volume of $0.1 \%(\mathrm{v} / \mathrm{v})$ sodium azide and kept at $4^{\circ} \mathrm{C}$. when not in use. A comparison was made of the activities of the stock preparations, unbuffered and buffered to $p \mathrm{H} 7.5$, which had been kept at $-20^{\circ} \mathrm{C}$. continuously, and the filtrate after the addition of sodium azide, which had been kept on the bench daily and at $4^{\circ} \mathrm{C}$. overnight. After a period of three months no differences could be found in the ability of these various solutions to change red cells.

Besides the crude culture filtrates of the strain of streptomyces a partially purified preparation was made available by Dr. van Heyningen and Dr. Born. The organism had been grown in deep aerated culture ; the enzyme material in solution was concentrated by evaporation of the fluid under reduced pressure and precipitation by saturation with ammonium sulphate and dried. The dried material, which has been termed "streptomyces lysin," was dissolved in $66 \%$ glycerol, and the stock solution was prepared at a concentration of $2 \mathrm{mg}$. $/ \mathrm{ml}$. The glycerol solution was stored at $4^{\circ} \mathrm{C}$. and showed no deterioration over a period of six months. For use the glycerol solution was diluted at least $1: 40(\mathrm{v} / \mathrm{v})$ with $0.1 \mathrm{M}$ phosphate buffer. With higher concentrations of the glycerol, haemolysis of the red cells occurs on washing the cells after treatment. The crude solutions were diluted with 4 to 9 volumes of buffer before use, depending on the activity.

\section{Preparation of Enzyme-treated Red Cells}

For brevity the preparation of the enzyme-treated red cell will be referred to as the P.E. (proteolytic enzyme) test or method subsequently in this paper.

Group $\mathrm{O}$ blood of suitable $\mathrm{Rh}$ type to include positive and negative controls for

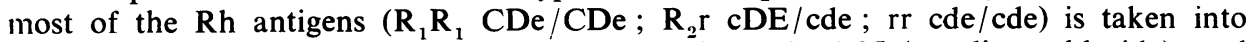
sodium citrate or citrate saline $(0.5 \%$ sodium citrate in $0.85 \%$ sodium chloride $)$, and washed three times with about 20 volumes of normal saline to remove the serum trypsin inhibitor. To one volume of packed washed cells 4 volumes of diluted enzyme in $0.1 \mathrm{M}$ phosphate buffer $p \mathrm{H} 7.7$ is added. The following enzyme solutions have been used, and the figures refer to the final concentrations in buffer as determined after standardization of the test.

\begin{tabular}{|c|c|c|c|c|c|c|c|}
\hline Crystalline trypsin. & Plaut & $\cdot$ & $\cdots$ & $\cdots$ & $\cdots$ & $\cdots$ & $1.0 \mathrm{mg} . / \mathrm{ml}$ \\
\hline "Ḧ " & Armour & 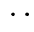 & . & $\cdots$ & . & $\ldots$ & $1.0 \mathrm{mg} . / \mathrm{ml}$. \\
\hline $\begin{array}{l}\text { B.D.H. commercial } \\
\text { refined }\end{array}$ & $\cdots$ & - & $\cdots$ & $\cdots$ & $\cdots$ & $\cdot$ & $\begin{array}{l}20 \mathrm{mg} . / \mathrm{ml} . \\
8-20 \mathrm{mg} . / \mathrm{ml} .\end{array}$ \\
\hline Crüde actinomyces & iltrate & $\begin{array}{l}\cdots \\
\cdots\end{array}$ & $\ldots$ & $\cdots$ & $\cdots$ & $\begin{array}{l}\cdots \\
\ldots\end{array}$ & $\begin{array}{l}1 / 5-1 / 10(v / v) \text { dilution } \\
\text { of crude filtrate }\end{array}$ \\
\hline Streptomyces lysin & & $\ldots$ & . & - & $\cdots$ & $\cdots$ & $0.05 \mathrm{mg} . / \mathrm{ml}$. \\
\hline
\end{tabular}


The mixture is gently shaken and placed in a water bath for 30 minutes at $37^{\circ} \mathrm{C}$. The cells are then washed once and made up to a $5 \%(\mathrm{v} / \mathrm{v})$ concentration in saline. These manipulations can be simply performed in graduated centrifuge tubes. The cells retain their new properties for at least 24 hours if prepared with sterile precautions and kept at $4^{\circ} \mathrm{C}$. Cells prepared in bulk and stored at $4^{\circ} \mathrm{C}$. as packed cells have remained active for four days.

Technique of P.E. Test.-In testing sera for the presence of the anti D antibody, $0.1 \mathrm{ml}$. or one large drop of the serum is pipetted into each of three small tubes $(5 \times 0.5 \mathrm{~cm}$. is a convenient size) and placed in a water bath at $37^{\circ} \mathrm{C}$. for a few minutes to equilibrate, and an equal volume of the warmed cell suspension of each type of cell is then added. The cell-serum mixture is shaken and allowed to sediment. The agglutination given by many incomplete antibodies will show within a few minutes of mixing, but we have found that the sediment pattern obtained after incubation for one half to one hour gives the most easily read results, as during the sedimentation a ragged edge is often seen. The concentration of the red cells is important, as too light a suspension may fail to give a clear-cut sediment pattern. After this time the majority of antibodies show the agglutinated cells to have formed a solid button, which by gently rotating the tube may be dislodged from the bottom of the tube, whereas the negative cells flow evenly down the side of the tube when it is tilted. The macroscopic reading is usually sufficient if negative control cells and a weak incomplete anti $D$ antibody are included in the test, for the agglutination is firm and not as easily dispersed by shaking as are the agglutinates obtained with saline agglutinins and the anti-globulin test.

A non-specific agglutination is shown by many sera with P.E. cells at $20^{\circ} \mathrm{C}$, , but by previously warming the cells and serum and by incubating the mixture for one half to one hour this can be abolished. In most cases it appears to be due to the enhancement of non-specific cold agglutinins, but a few sera have been encountered which give a slight panagglutination just visible macroscopically at $37^{\circ} \mathrm{C}$. with all cell suspensions, and has been more often observed with cells which have been treated with trypsin than with streptomyces lysin. In most cases it indicates over-treatment of the cells with enzyme, and precautions against its occurrence are discussed under standardization of the test.

Standardization of the Test.-The changes in the red cells after treatment by proteolytic enzymes can be measured by the degree of agglutination and end-point titre obtained on titration of a standard incomplete antibody. Variations in cell and enzyme concentration, $p \mathrm{H}$, and time of incubation result in differences in the sensitivity of the test as judged by the figures given on titration; accordingly the maximum titre with a standard incomplete antibody, with no panagglutination of the cells with normal serum, has been deemed to represent the full change in the cells and has been used as a standard.

Two incomplete anti D sera (titre in albumin 1:8-16) were selected for the standardization tests and kept at $-20^{\circ} \mathrm{C}$., and in these experiments serial dilutions of the sera were made in 1-ml. volumes and the various serum dilutions transferred by standard droppers to sets of small tubes. One volume of packed, three times washed, cells and four volumes of enzyme solution, giving a cell concentration of $20 \%$, was chosen arbitrarily as being easy to work with, and both the concentrations of the enzymes and the time of incubation with the red cells were varied. Since normal serum contains a potent inhibitor of proteolytic enzymes the reactions could be stopped at any particular time by the addition of an excess of normal serum before washing or by rapidly spinning down and washing the red cells three times with saline. The cells after treatment were made up to a $5 \%$ concentration in saline, and the amount of change produced in the red cells was measured by titrating the cells against a standard incomplete serum. 
The majority of the standardization experiments were performed with one batch of streptomyces lysin and crystalline trypsin (Plaut Research Laboratory). The concentrations of the other enzyme preparations were adjusted to give equivalent results, and under the standard conditions $1 \mathrm{mg}$. $/ \mathrm{ml}$. of crystalline trypsin (Plaut Research Co.) was equivalent to $1 \mathrm{mg}$. $/ \mathrm{ml}$. crystalline trypsin (Armour Laboratories), 8 and $20 \mathrm{mg} . / \mathrm{ml}$. refined B.D.H. trypsin (two batches), $20 \mathrm{mg} . / \mathrm{ml}$. B.D.H. trypsin, and $0.05 \mathrm{mg} . / \mathrm{ml}$. streptomyces lysin.

TABLE I

Effect on the ANTibody Trtre of InCreasing the Enzyme Concentration and InCUbation Time With Rh-POSITIVe Cells

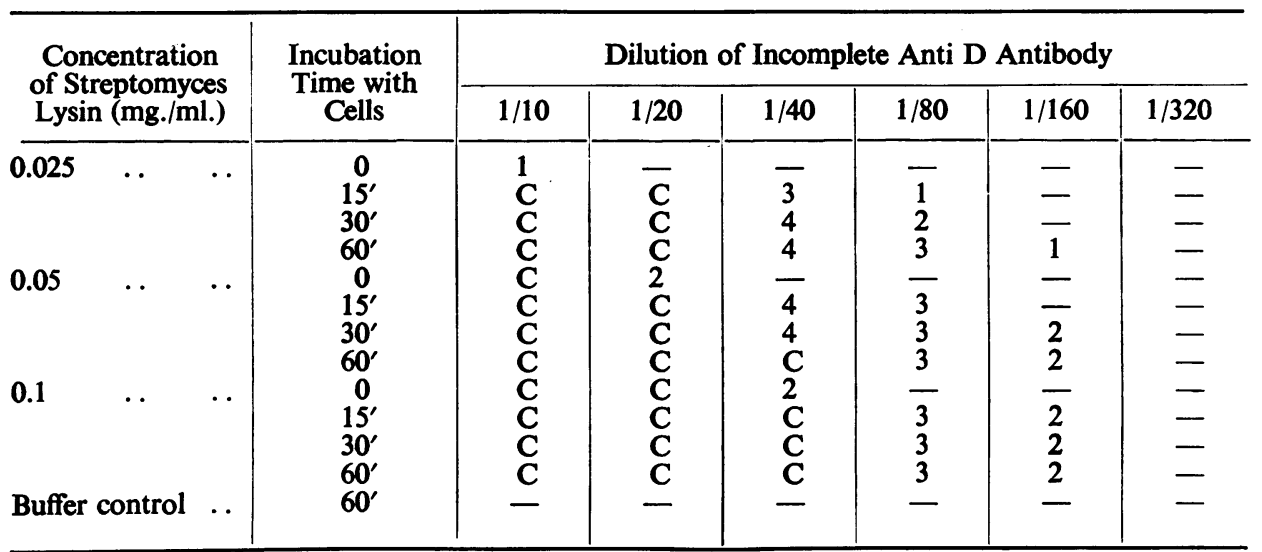

$\mathrm{C}=$ single clump of cells; $4=3-4$ large agglutinates; $3=$ several agglutinates; $2=$ small agglutinates visible macroscopically; $1=\mathbf{a}$ few very small agglutinates.

\section{Results}

Table I shows the results obtained on titration of red cells exposed to increasing concentrations of streptomyces lysin at 15-minute intervals up to one hour. With a concentration of enzyme of $0.1 \mathrm{mg}$. $/ \mathrm{ml}$. a maximum titre was obtained within 15 minutes, and no change in the pattern or type of agglutination was noted by prolonging incubation for a further 45 minutes. The enzyme used at half this concentration gave the same reading after 30 and 60 minutes, and with the enzyme used at a concentration of $0.025 \mathrm{mg}$. $/ \mathrm{ml}$. this titre was barely reached within one hour.

With weaker concentrations of enzyme full activity of the cells could not be obtained even by prolonging the period of incubation up to eight hours, as shown in Table II. This is presumably due to the degradation of enzyme at $37^{\circ} \mathrm{C}$. at

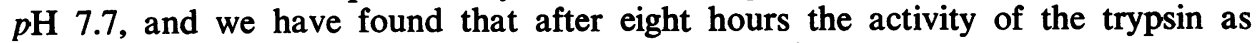
measured by its action on casein was reduced by $50 \%$.

Cells exposed either to trypsin or streptomyces lysin develop non-specific agglutination with normal sera if the concentration of the enzyme or the time of incubation is excessive. This panagglutination occurs more rapidly with higher concentrations of enzyme and varies with different sera. Many sera never show non-specific agglutination, but a few show panagglutination with P.E. cells at the stage of development of the maximum titre as may be seen in Table III, which shows the effect of excessive concentration and time. The sera numbered 3 and 7 were both from 
TABLE II

Failure of Weak Enzyme Solutions to give a Maximum Titre of the Standard ANTIBODY

\begin{tabular}{|c|c|c|c|c|c|c|c|c|}
\hline \multirow{2}{*}{$\begin{array}{l}\text { Concentration } \\
\text { of Enzyme } \\
\text { (mg./ml.) }\end{array}$} & \multirow{2}{*}{$\begin{array}{l}\text { Incubation } \\
\text { Time with } \\
\text { Cells }\end{array}$} & \multicolumn{6}{|c|}{ Titration of Incomplete Anti D Antibody } & \multirow{2}{*}{$\begin{array}{l}\text { Normal } \\
\text { Serum }\end{array}$} \\
\hline & & $1 / 10$ & $1 / 20$ & $1 / 40$ & $1 / 80$ & $1 / 160$ & $1 / 320$ & \\
\hline $\begin{array}{c}\text { Trypsin, } 1.0 \\
\text { Streptomyces } \\
\text { lysin, } 0.05\end{array}$ & $\begin{array}{c}30^{\prime} \\
2 \mathrm{hr} . \\
4 \quad, \\
8 \quad, \\
300^{\prime \prime} \\
30^{\prime}\end{array}$ & $\begin{array}{l}C \\
C \\
C \\
C \\
C \\
C \\
C\end{array}$ & $\begin{array}{l}C \\
C \\
C \\
C \\
C \\
C \\
C\end{array}$ & $\begin{array}{l}2 \\
2 \\
2 \\
2 \\
\mathrm{C} \\
\mathrm{C}\end{array}$ & $\begin{array}{l}- \\
2 \\
2 \\
4 \\
3\end{array}$ & $\begin{array}{l}- \\
\bar{Z} \\
? \\
1 \\
2\end{array}$ & $\begin{array}{l}\overline{-} \\
\bar{?} \\
-\end{array}$ & $\begin{array}{l}\overline{-} \\
\frac{2}{2} \\
-\end{array}$ \\
\hline
\end{tabular}

TABLE III

Non-SPecific Reaction Obtained with Excessive Concentration of Enzyme (Crystalline Trypsin) OR Time of Incubation with Red Cells

\begin{tabular}{|c|c|c|c|c|c|c|c|c|c|c|c|c|c|c|c|}
\hline \multirow{2}{*}{$\begin{array}{c}\text { Incubation } \\
\text { Time } \\
\text { (Hours) }\end{array}$} & \multirow{2}{*}{$\begin{array}{l}\text { Concen- } \\
\text { tration } \\
\text { of } \\
\text { Enzyme } \\
\text { (mg./ml.) }\end{array}$} & \multicolumn{12}{|c|}{ Non-antibody-containing Sera } & \multirow{2}{*}{ Saline } & \multirow{2}{*}{$\begin{array}{c}\text { Titre } \\
\text { Against } \\
\text { Standard } \\
\text { Anti D }\end{array}$} \\
\hline & & 1 & 2 & 3 & 4 & 5 & 6 & 7 & 8 & 9 & 10 & 11 & 12 & & \\
\hline 2 & $\begin{array}{l}2 \\
1 \\
0.5 \\
2 \\
1 \\
0.5 \\
2\end{array}$ & $\begin{array}{l}1 \\
1 \\
1 \\
- \\
-\end{array}$ & $\begin{array}{l}- \\
= \\
z \\
-\end{array}$ & $\begin{array}{l}2 \\
2 \\
1 \\
1 \\
1 \\
1 \\
1\end{array}$ & $\begin{array}{l}- \\
= \\
= \\
=\end{array}$ & $\begin{array}{l}\frac{1}{1} \\
\frac{1}{1}\end{array}$ & $\begin{array}{l}\frac{1}{1} \\
\frac{1}{-} \\
-\end{array}$ & $\begin{array}{l}2 \\
2 \\
2 \\
2 \\
2 \\
1 \\
1\end{array}$ & $\begin{array}{l}= \\
= \\
= \\
=\end{array}$ & $\begin{array}{l}= \\
\bar{z} \\
= \\
=\end{array}$ & $\begin{array}{l}= \\
= \\
= \\
=\end{array}$ & $\begin{array}{l}E \\
= \\
= \\
-\end{array}$ & $\begin{array}{l}= \\
= \\
= \\
=\end{array}$ & $\begin{array}{l}= \\
= \\
= \\
=\end{array}$ & $\begin{array}{l}1 / 320 \\
1 / 320 \\
1 / 160 \\
1 / 320 \\
1 / 320 \\
1 / 160 \\
1 / 320\end{array}$ \\
\hline & $* 1$ & - & - & - & - & - & - & 1 & $1-$ & - & - & - & - & - & $1 / 320$ \\
\hline$\frac{1}{4}$ & $\begin{array}{l}0.5 \\
2 \\
1 \\
0.5\end{array}$ & E & $\begin{array}{l}- \\
-\end{array}$ & - & $\begin{array}{l}\text { - } \\
\text { - }\end{array}$ & E & $\begin{array}{l}\text { - } \\
-\end{array}$ & $\begin{array}{l}\overline{1} \\
1 \\
-\end{array}$ & $\begin{array}{l}= \\
=\end{array}$ & $\bar{z}$ & $\begin{array}{l}\overline{-} \\
-\end{array}$ & $\begin{array}{l}\text { E } \\
\text { - }\end{array}$ & $\begin{array}{l}\text { 二 } \\
\text { - }\end{array}$ & $\begin{array}{l}- \\
-\end{array}$ & $\begin{array}{l}1 / 160 \\
1 / 320 \\
1 / 80 \\
1 / 40\end{array}$ \\
\hline
\end{tabular}

* The normal time of incubation and concentration of trypsin is set in a panel.

individuals with severe staphylococcal infections, and it may be that their sera contained a non-specific factor causing a type of pseudo-agglutination. From the point of view of detection of specific antibody these sera react with the patient's cells in the same manner as with all other cells, and the factor causing agglutination is not absorbable with P.E. cells and is abolished by dilution of the serum with an equal volume of saline. In this way it is analogous to the pseudo-agglutination due to rouleaux formation, which is often seen in sera from patients with high sedimentation rates, though this type of pseudo-agglutination is much reduced with P.E. cells and has rarely been observed.

The effect of various diluents on the panagglutination was tried by washing and resuspending the cells after excessive treatment with trypsin, with normal saline, $0.5 \%$ sodium citrate in $0.85 \%$ saline, $3.8 \%$ citrate, $0.1 \mathrm{M}$ phosphate buffer and $\mathrm{Ca}$ borate buffer $p \mathrm{H}$ 7.2. No differences were observed with the panagglutinating sera 
or the normal sera with the various diluents, and the titre against the anti D antibody remained the same, though with $3.8 \%$ sodium citrate the agglutination with this antibody was more easily broken up.

One serum has been encountered which has given a strong positive agglutination reaction with streptomyces lysin-treated cells, to a titre of $1: 8$, but all other antibody tests, including the trypsin test, were negative. The antibody was absorbable by streptomyces lysin-treated cells though not by trypsin-treated cells or by normal cells, and appeared to be a specific antibody analogous to that produced by the immunization of rabbits with streptomyces lysin-treated cells. Such sera, though rare, need to be critically analysed as they may simulate the results obtained with the sera of acquired haemolytic anaemias (Wright et al., 1949). In this case there was no evidence of increased haemolysis ( $\mathrm{Hb} 15 \mathrm{~g} . / 100 \mathrm{ml}$., reticulocytes $0.6 \%$, direct Coombs test negative, cold agglutinins titre $1: 2$ ).

The standardization of the various brands of trypsin by their caseinolytic activity (Kunitz, 1947) has been attempted, and it was found that the caseinolytic activities did not bear any constant relationship to the activity in the production of P.E. cells. Table IV shows the degree of agglutination obtained with an incomplete anti D

TABLE IV

Sensitivity of P.E. Cells* Incubated with Various Brands of Trypsin at Equivalent Caseinolytic ACtivities WTth an INCOMPLETE ANTI D ANTIBOdY

\begin{tabular}{|c|c|c|c|c|c|c|c|}
\hline \multirow{2}{*}{ Trypsins } & \multirow{2}{*}{$\begin{array}{c}\text { Concentration } \\
\text { (mg./ml.) }\end{array}$} & \multicolumn{6}{|c|}{ Dilutions of Incomplete Anti D Antibody } \\
\hline & & $1 / 10$ & $1 / 20$ & $1 / 40$ & $1 / 80$ & $1 / 160$ & $1 / 320$ \\
\hline 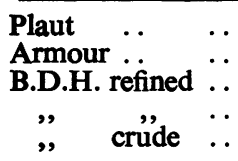 & $\begin{array}{l}1.0 \\
0.48 \\
6.56 \\
7.67 \\
5.79\end{array}$ & $\begin{array}{l}\mathbf{C} \\
\mathbf{C} \\
\mathbf{C} \\
\mathbf{C} \\
\mathbf{C}\end{array}$ & $\begin{array}{l}\mathrm{C} \\
\mathrm{C} \\
\mathrm{C} \\
\mathrm{C} \\
4\end{array}$ & $\begin{array}{l}\mathbf{C} \\
\mathbf{C} \\
\mathbf{C} \\
\mathbf{C} \\
3\end{array}$ & $\begin{array}{l}3 \\
2 \\
3 \\
3 \\
-\end{array}$ & $\begin{array}{l}\frac{2}{2} \\
\frac{1}{-}\end{array}$ & $\begin{array}{l}\bar{z} \\
\bar{z}\end{array}$ \\
\hline
\end{tabular}

* Cells sensitized with 4 volumes of enzyme for 30 minutes.

antibody with the various types of trypsin at equivalent caseinolytic activities. The effective range of concentration of trypsin for the production of P.E. cells appears to be very high as the concentration of enzyme necessary for the trypsinization of the cells was 40 times that used for the determination of the caseinolytic activities. This may be due to the fact that the surface of the red cell is a living membrane and therefore relatively insusceptible to proteolysis, or may be explicable as the action of an unidentified enzyme present as a contaminant in trypsin and varying in concentration during refinement and crystallization.

\section{Tests with Antibodies Detected with the Albumin and Coombs Tests}

Eighty-six sera known to contain incomplete anti D antibodies, which had been stored for one to three years at $-20^{\circ} \mathrm{C}$., were examined using the P.E. method in parallel with the albumin test (using $25 \%$ human albumin) and the antiglobulin (Coombs) test. With the P.E. method all these sera with the Rh-positive cells gave a $4+$ reaction, and in most the cells formed a solid clump, whereas the $R h$-negative control cells were completely negative ; among them were three sera that had given 
prozones with albumin and several which had given negative reactions with the Coombs test. The results indicated that the P.E. test was the more sensitive method for the detection of antibodies, and this has been confirmed by the higher titration values obtained by the P.E. method and also by the results obtained with the test in unselected sera sent for antibody determinations.

During the past two years 1,176 sera have been examined by the P.E. test in parallel with the routine methods with saline, $25 \%$ human albumin, and anti-globulin tests. The majority of the sera were from Rh-negative antenatal patients, though about 300 were from a series of post-transfusion cases whose sera were being examined for the development of specific antibodies. Sixty-four of these sera were found to contain anti D antibodies, and the results are shown in Table V.

TABLE V

ANalysis of the Results of ANTiBody Tests on 64 Sera

\begin{tabular}{|c|c|c|c|c|c|c|c|}
\hline & \multirow{2}{*}{$\begin{array}{c}\text { No. } \\
\text { Positive }\end{array}$} & \multicolumn{2}{|c|}{ Albumin } & \multicolumn{2}{|c|}{ Coombs } & \multicolumn{2}{|c|}{$\begin{array}{l}\text { Proteolytic } \\
\text { Enzyme }\end{array}$} \\
\hline & & + & - ve & + & - ve & + & $-\mathrm{ve}$ \\
\hline $\begin{array}{l}\text { Saline agglutinating antibodies } \\
\text {-not enhanced } \\
\text { Weak agglutination with saline; } \\
\text { stronger with tests for incom- } \\
\text { plete antibodies } \quad . \\
\text { Incomplete antibodies .. } \quad . .\end{array}$ & $\begin{array}{r}8 \\
54\end{array}$ & $\begin{array}{r}8 \\
49\end{array}$ & $\begin{array}{l}\mathbf{0} \\
5\end{array}$ & $\begin{array}{r}6 \\
36\end{array}$ & $2 ?$ & $\begin{array}{r}8 \\
54\end{array}$ & $\begin{array}{l}0 \\
0\end{array}$ \\
\hline
\end{tabular}

In the sera of several of the antenatal patients the P.E. test gave the only positive result on the first testing, but as the pregnancy proceeded subsequent observations showed all the tests for incomplete antibodies becoming positive. The following cases illustrate this.

Mrs. C. F.-Para. 1. First child normal. Tested when three months pregnant. P.E. test ++ . All other tests negative. Tested when eight months pregnant. P.E. test +++ . Other tests weakly positive. Tested when eight and a half months pregnant. Incomplete anti $D$ antibody (titre 1:1 albumin). Cord blood of infant was group $R_{1} r$; Coombs test positive. Mildly affected infant, who recovered with one transfusion.

Mrs. E. N.-Para. 2. Both children normal. Tested when six months pregnant. P.E. test ++++ . Albumin ? + . Indirect Coombs test negative. Tested when eight months pregnant. P.E. test ++++ . Incomplete anti $D$ (titre $1: 4$ albumin). Cord blood of infant was group $R_{1} r$; Coombs test positive. The infant was transfused at 14 days because of the development of neonatal anaemia.

Mrs. H.-In 1947 the third child died with icterus gravis aged 4 days. Maternal antibodies agglutinated anti D $1: 4$. On October 17, 1949, Mrs. H. was admitted with a miscarriage at three months. Antibody tests: saline 0; albumin +; Coombs test $?+$; P.E. test ++++ .

The ease of interpretation and the clear-cut results obtained when the results with other tests are equivocal have led us to use the P.E. test as the final arbiter as to whether anti D antibodies are present or not. With some batches of albumin the tendency for rouleaux formation often makes the differentiation from true agglutination difficult to interpret, and with weak antibodies the antiglobulin test very often fails to show agglutination. 
Titrations.-Agglutinating anti D antibodies which show no enhancement of titre by the Coombs technique and a lowered titre in albumin have not shown more than one serial dilution difference in titre with P.E.-treated cells, though the agglutination at the various dilutions was much firmer than with normal cells. The example illustrated in Table VI was from a woman in whom an antibody test was negative at

TABLE VI

The Reactions of an Agglutinating ANti D Serum with Normal and P.E.-Treated CELLS

\begin{tabular}{|c|c|c|c|c|c|c|c|c|c|c|}
\hline & & & \multicolumn{8}{|c|}{ Mrs. S. Serum at Delivery } \\
\hline & & & \multicolumn{8}{|c|}{ Dilution of Antibody } \\
\hline & & & $1: 1$ & $1: 2$ & $1: 4$ & $1: 8$ & $1: 16$ & $1: 32$ & $1: 64$ & $1: 128$ \\
\hline $\begin{array}{l}\text { Saline } \\
\text { P.E. cells }\end{array}$ & . & $\begin{array}{l}\ldots \\
\ldots\end{array}$ & $\begin{array}{l}4 \\
\mathrm{C}\end{array}$ & $\begin{array}{l}4 \\
\mathrm{C}\end{array}$ & $\begin{array}{l}3 \\
\mathrm{C}\end{array}$ & $\begin{array}{l}3 \\
\mathrm{C}\end{array}$ & $\begin{array}{l}3 \\
4\end{array}$ & $\begin{array}{l}2 \\
3\end{array}$ & $\begin{array}{l}1 \\
2\end{array}$ & $\overline{1}$ \\
\hline
\end{tabular}

seven and a half months' gestation but who showed an agglutinating anti D antibody for one month before delivery; the cord blood sample gave a very weak positive direct Coombs test, and the infant remained clinically normal.

With sera containing incomplete antibodies, however, the P.E.-treated cells have shown higher titration values than any other method. The average increase in titre being about four to 20 times above the Coombs or albumin titration values, Table VII

TABLE VII

The Titres Obtained with the Various Tests for Six ANTi D Sera

\begin{tabular}{|c|c|c|c|c|c|c|}
\hline & $\mathrm{Tu}$ & Di & $\mathbf{B i}$ & $\mathrm{Bu}$ & $\mathbf{B a}$ & Mo \\
\hline Saline "Conglutination ", (Wiener, 1945) & $\begin{array}{l}0 \\
1 / 32\end{array}$ & $\begin{array}{l}1 / 2 \\
1 / 32\end{array}$ & $\begin{array}{l}0 \\
1 / 8\end{array}$ & $\begin{array}{l}0 \\
1 / 2\end{array}$ & $\begin{array}{l}1 / 4 \\
1 / 16\end{array}$ & $\begin{array}{l}0 \\
1 / 4\end{array}$ \\
\hline Dilutions in serum, cell suspended in & & & & & & \\
\hline $25 \%$ albumin $\ddot{2}$ in & $1 / 64$ & $1 / 16$ & $1 / 16$ & $1 / 2$ & $1 / 16$ & $1 / 4$ \\
\hline $\begin{array}{l}\text { Dilutions and cells in albumin (Diamond } \\
\text { and Denton, 1945) }\end{array}$ & $1 / 16$ & $1 / 4$ & $1 / 8$ & $1 / 4$ & $1 / 8$ & $1 / 4$ \\
\hline $\begin{array}{l}3 \text { parts serum } 1 \text { part albumin (Wiener, } \\
\text { Hurst, and Sonn-Gordon, 1947) }\end{array}$ & $1 / 128$ & $1 / 32$ & $1 / 64$ & $1 / 8$ & $1 / 64$ & $1 / 4$ \\
\hline $\begin{array}{r}\text { Antiglobulin test } \\
\text { and Race, 1945) }\end{array}$ & $1 / 32$ & $1 / 8$ & $1 / 4$ & $1 / 8$ & $1 / 32$ & $1 / 8$ \\
\hline 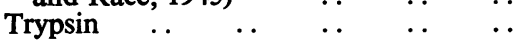 & $1 / 256$ & $1 / 128$ & $1 / 64$ & $1 / 32$ & $1 / 128$ & $1 / 16$ \\
\hline
\end{tabular}

sets out the final titres of four incomplete sera and two sera containing both agglutinating and incomplete antibodies examined by five methods for incomplete antibodies. These six sera were all tested within three weeks of collecting the samples. As shown in Tables I and VI the end-points of the titrations with P.E. cells is very sharp, and the change from a $4+$ or complete agglutination to no reaction covers only two or three tubes in the serial dilution.

Other $\mathbf{R h}$ Antibodies.-Incomplete antibodies of specificities anti C, E, c, e, and anti $C^{w}$ have shown agglutination with the P.E. test and except for the anti $C^{w}$ 
serum have shown much the same order of increased titration values as was seen with the incomplete anti $\mathrm{D}$ antibodies. An incomplete anti $\mathrm{E}$ antibody which

TABLE VIII

ANTIBodies of Specificity ANTI C, E, c, e, C'

\begin{tabular}{|c|c|c|c|c|c|c|c|c|}
\hline \multirow{3}{*}{\multicolumn{2}{|c|}{ Serum }} & & \multirow{3}{*}{ Cell Type } & \multicolumn{5}{|c|}{ Titres Given with Different Techniques } \\
\hline & & & & \multirow[b]{2}{*}{ Saline } & \multirow[b]{2}{*}{ Albumin } & \multirow[b]{2}{*}{ Coombs } & \multicolumn{2}{|c|}{ P.E. Test } \\
\hline & & & & & & & Trypsin & $\begin{array}{l}\text { Streptomyces } \\
\text { Lysin }\end{array}$ \\
\hline 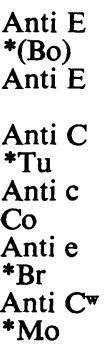 & $\begin{array}{l}. \\
\ldots \\
. \\
\ldots \\
\ldots \\
\ldots\end{array}$ & $\begin{array}{l}\cdots \\
\ldots \\
\cdots \\
\cdots \\
\cdots \\
.\end{array}$ & 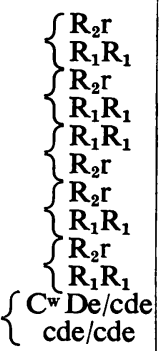 & $\begin{array}{c}0 \\
0 \\
1: 4 \\
0 \\
0 \\
0 \\
0 \\
0 \\
0 \\
0 \\
0 \\
0\end{array}$ & $\begin{array}{c}1: 2 \\
0 \\
1: 8 \\
0 \\
1: 4 \\
0 \\
1: 4 \\
0 \\
1: 4 \\
1: 16 \\
1: 2 \\
0\end{array}$ & $\begin{array}{c}1: 2 \\
0 \\
1: 32 \\
0 \\
1: 2 \\
0 \\
1: 8 \\
0 \\
1: 2 \\
1: 32 \\
1: 2 \\
0\end{array}$ & $\begin{array}{c}1: 8 \\
0 \\
1: 256 \\
0 \\
1: 64 \\
0 \\
1: 64 \\
0 \\
1: 8 \\
1: 256 \\
0 \\
0\end{array}$ & $\begin{array}{c}1: 8 \\
0 \\
1: 128 \\
0 \\
1: 32 \\
0 \\
1: 64 \\
0 \\
1: 8 \\
1: 256 \\
1: 2 \\
0\end{array}$ \\
\hline
\end{tabular}

* Sera given by Dr. Race.

developed after transfusion was first identified by a positive P.E. test and later became positive with the albumin test. The lack of increased titre of the anti $\mathrm{C}^{\mathrm{w}}$ serum may be explained by long storage or may be a fundamental lack of reaction of the antibody with P.E. cells as has been seen with incomplete antibodies of other specificities. In view of the infrequent occurrence of the anti C, E, c, e, antibodies and their value in genotyping, it seems that it would be possible to utilize the P.E. method in genotyping with incomplete antibodies giving low titres by the other methods.

Antibodies of Other Specificities.-Investigations with the P.E. method on agglutinating and incomplete antibodies unrelated to the $\mathrm{Rh}$ system have shown various types of reaction. In the systems involving anti $\mathrm{A}$, anti $\mathrm{B}$, anti $\mathrm{Lu}^{\mathrm{a}}$, anti $\mathrm{Le}^{\mathrm{a}}$, and anti $P$ agglutinating antibodies no significant differences were obtained in the titre though there was more intense agglutination with P.E. cells than with normal cells. An incomplete anti $\mathrm{Le}^{\mathrm{a}}$ serum showed no reaction.

With agglutinating sera of specificity anti $M$, anti $N$, and anti $S$, cells treated with crystalline trypsin (Plaut Research Co.) showed a slight increase of titre and avidity of reaction, but with all other brands of trypsin and also with the proteolytic enzyme from Streptomyces albus there was destruction of the antigen locus, the red cells after treatment giving no agglutination and failing to absorb specific antibody. The rate of destruction of these loci varied with the various enzyme preparations and was most rapid with streptomyces lysin. An incomplete anti $S$ gave agglutination with trypsin-treated cells. One example each of an incomplete anti Fy and anti Kell showed no agglutination with either trypsin or streptomyces lysin-treated cells. 
The non-specific incomplete antibody found in cases of acquired haemolytic anaemia has been found to give agglutination with P.E. cells, but as an antibody reacting with cells treated with streptomyces lysin has been observed in an apparently normal individual, it would appear that a strict evaluation of its significance should be made in any individual in which such a reaction is found.

These findings are summarized in Table IX and will be discussed more fully in a subsequent paper on the effect of proteolytic enzymes on the surface of the red

TABLE IX

The Proteolytic Enzyme Test with Sera of Various Specificities

\begin{tabular}{|c|c|c|c|c|c|c|c|c|}
\hline \multicolumn{3}{|c|}{ Specificity } & \multicolumn{3}{|c|}{ Type of Serum } & \multicolumn{2}{|c|}{$\begin{array}{l}\text { Trypsin } \\
\text { (Plaut) }\end{array}$} & $\begin{array}{l}\text { Streptomyces } \\
\text { Lysin }\end{array}$ \\
\hline \multirow{2}{*}{$\begin{array}{r}\text { Anti A } \\
, \text { B } \\
\end{array}$} & \multirow[t]{2}{*}{$\cdots$} & \multirow[t]{2}{*}{$\cdots$} & \multicolumn{3}{|c|}{ Non-immune, agglutinating } & \multicolumn{2}{|c|}{$\begin{array}{l}\text { Slight increase in } \\
\text { titre and avidity }\end{array}$} & \multirow{2}{*}{$\begin{array}{c}\text { Slight increase in } \\
\text { titre and avidity } \\
,,\end{array}$} \\
\hline & & & , & , & ,' &, & , & \\
\hline Anti $\mathbf{P}$ & . & $\cdots$ & , , & , &, & , , &, & , , , , \\
\hline $\left.\begin{array}{r}\text { Anti } \\
,, N \\
N\end{array}\right\}$ & $\cdots$ & $\cdots$ & \multicolumn{2}{|c|}{, } & ,", & \multicolumn{2}{|l|}{,} & $\begin{array}{c}\text { No reaction } \\
,,,,\end{array}$ \\
\hline Anti S & $\cdots$ & $\cdots$ & \multicolumn{3}{|c|}{$\begin{array}{l}\text { ? Immune, agglutinating } \\
\quad,, \quad \text { incomplete }\end{array}$} & \multicolumn{2}{|l|}{,, } & $\begin{array}{ll}, & , \\
, & ,\end{array}$ \\
\hline Anti Le ${ }^{a}$ & . & . & & \multicolumn{2}{|r|}{$\begin{array}{l}\text { agglutinating } \\
\text { incomplete }\end{array}$} & \multicolumn{2}{|c|}{$\begin{array}{c},,, \\
\text { Haemolysis }\end{array}$} & $\begin{array}{l}\text { Slight increase in } \\
\text { titre and avidity } \\
\text { No reaction }\end{array}$ \\
\hline Anti $\mathrm{Lu}^{\mathrm{a} *}$ & $\cdots$ & $\cdots$ & & \multicolumn{2}{|r|}{ agglutinating } & \multicolumn{2}{|c|}{ No change } & No change \\
\hline Anti Kell* & $\cdots$ & $\cdots$ & & \multicolumn{2}{|r|}{ incomplete } & \multicolumn{2}{|c|}{ No reaction } & No reaction \\
\hline Anti Fy $\dagger \ldots$ & $\cdots$ & $\cdots$ & &, &, &, & & , , , , \\
\hline $\begin{array}{r}\text { Immune antit } \\
\text { haemolytic } \\
\text { positive } \mathrm{Cc}\end{array}$ & $\begin{array}{l}\text { y fo } \\
\text { dem } \\
\text { bs }\end{array}$ & $\begin{array}{l}\text { in } \\
\text { vith } \\
\cdots\end{array}$ & &, & , & Agglut & tion & Agglutination \\
\hline
\end{tabular}

* Serum given by Dr. Mourant. † Serum given by Dr. Mollison.

cell. Except for the immune antibody in cases of acquired haemolytic anaemia only one serum of each type has been tested, and they were all of human origin.

\section{Discussion}

The recognition of the importance of the incomplete form of the anti D antibody has led to the development of numerous techniques for its identification. Many are not sufficiently sensitive for routine work, and others are cumbersome or impractical where large numbers of tests, such as those connected with antenatal work, have to be carried out. The P.E. test described here has received an extensive trial over the past two years and has shown many advantages in routine work. Rouleaux formation, which is difficult to overcome with any of the methods in which enhancement of agglutination is obtained with serum, plasma, or albumin, is largely abolished, and the Coombs test is apt to be laborious for routine work 
because of the washings involved. The preparation of the cells by enzyme treatment can be performed in bulk, and the cells are stable for at least 24 hours if kept sterile at $4^{\circ} \mathrm{C}$., thus allowing emergency work to be accomplished very easily and rapidly. The results obtained have shown that the test is more sensitive than the albumin test and that once an enzyme preparation has been standardized the reagents remain stable for several months. Although crude enzyme preparations can be used, it would seem desirable to use the more refined products, and especially valuable would be a supply of refined streptomyces lysin, which in our hands has given much less non-specific reactions combined with more rapid activity than crystalline trypsin. The differences observed with various brands of trypsin and streptomyces lysin with sera of various specificities have shown that the presence of contaminating proteolytic enzymes which easily destroy some blood groups of the red cells make the test unreliable as a routine method for all types of antibody determinations, but for the $\mathrm{Rh}$ group it has never failed to show agglutination with incomplete antibodies.

\section{Summary}

The technique and standardization of a method for the detection of $\mathrm{Rh}$ antibodies using P.E.-treated red cells have been described, together with the results of its use in routine tests for immune iso-agglutinins. The test has been found to enhance agglutination and diminish rouleaux formation with all types of incomplete anti $\mathbf{R h}$ antibodies, and to be the most sensitive method for their detection. The pattern of agglutination with saline-agglutinating sera of specificity anti D, anti A, anti B, anti $\mathrm{Le}^{\mathrm{a}}$, anti $\mathrm{Lu}^{\mathrm{a}}$, and anti $\mathrm{P}$ is not altered when using enzyme-treated cells, but the agglutination with anti $\mathrm{M}$, anti $\mathrm{N}$, and anti $\mathrm{S}$ anti sera may be completely abolished with some brands of trypsin, and agglutination cannot be obtained with incomplete antibodies of specificity anti Kell and anti Fy.

We are greatly indebted to Dr. van Heyningen and Dr. Born for much help and advice and most generous gifts of streptomyces lysin; to Dr. Race for samples of incomplete sera of specificity anti $\mathrm{C}$, anti $\mathrm{C}^{\mathrm{w}}$, anti $\mathrm{e}$, and anti $\mathrm{E}$, to Dr. Mourant for anti Kell and anti $\mathrm{Lu}^{\mathrm{a}}$, and Dr. Mollison for anti Fy.

\section{REFERENCES}

Coombs, R. R. A., Mourant, A. E., and Race, R. R. (1945). Brit. J. exp. Path., $26,255$.

Diamond, L. K., and Denton, R. L. (1945). J. Lab. clin. Med., 30, 821 .

Kunitz, M. (1947). J. gen. Physiol., 30, 291.

Maxted, W. R. (1948). Lancet, 2, 255.

Morton, J. A., and Pickles, M. M. (1947). Nature, Lond., 159, 779.

Wheeler, W. E., Luhby, A. L., and Scholl, M. L. L. (1950). J. Immunol., 65, 39.

Wiener, A. S. (1945). J. Lab. clin. Med., 30, 662.

- Hurst, J. G., and Sonn-Gordon, E. B. (1947). J. exp. Med., 86, 267.

Wright, C., Dodd, M. C., and Bouroncle, B. A. (1949). J. Lab. clin. Med., 34, 1768. 